\title{
SISTEM PAKAR DIAGNOSA GEJALA AWAL PENYAKIT AKIBAT VIRUS PADA ANAK BERBASIS MOBILE DENGAN FORWARD CHAINING
}

\author{
Mhd Ridhon Ritonga ${ }^{1}$, Solikhun ${ }^{2}$, Muhammad Ridwan \\ Lubis $^{3}$,Agus Perdana Windarto ${ }^{4}$ \\ ${ }^{1}$ Mahasiswa Sistem Informasi, STIKOM Tunas Bangsa Pematangsiantar \\ ${ }^{2,3}$ Dosen AMIK Tunas Bangsa Pematangsiantar \\ ${ }^{4}$ Dosen STIKOM Tunas Bangsa Pematangsiantar \\ 1,2,3,4 Jln.Jenderal Sudirman Blok A No.1/2/3 Pematangsiantar \\ ridhon_ritonga@yahoo.com,solikhun@amiktunasbangsa.ac.id,ridwanlubis@amiktunasbangsa.ac.id, \\ agus.perdana@amiktunasbangsa.ac.id
}

\begin{abstract}
Abstrak-Sistem pakar adalah sistem berbasis komputer yang menggunakan knowledge, fakta dan penalaran untuk memecahkan masalah yang hanya dapat dipecahkan oleh seorang pakar. Virus adalah salah satu penyakit yang rentan dialamin anak-anak karena sistem kekebalan pada tubuh belum terbangun secara sempurna. Sebahagian besarorangtua tidak mengenali gejala penyakit pada tubuh anak yang timbul diakibatkan infeksi virus. Sistem pakar dibuat untuk mendiagnosa gejala awal penyakit akibat virus anak yang disebabkan oleh infeksi virus. Proses diagnosa dimulai dengan cara user menjawab pertanyaan-pertanyaan berupa gejala yang diderita oleh pengguna. Alasan penelitian ini dilakukankarena keterbatasan dokter dan banyaknya pasien anak-anakyang butuh penanganan dini terhadapat gejala penyakit awal yang disebabkan oleh virus. Alat bantu berupa sistem pakar ini merupakan solusi dimana sistem mampu bertindak sebagaimana layaknya seorang pakar. Sistem pakar ini berbasis mobile sehingga dapat diakses kapanpun dan di manapun oleh pengguna selama mereka terhubung dengan internet dan handphone.Hasil dari penelitian dapat memberikan pertolongan kepada orangtua terhadat anak-anaknya untuk mendiagnosis gejala awal yang dialamin oleh penderita sebelum ditanganin oleh ahlinya, sehingga orang tua dapat melakukan tindakan yang tepat.
\end{abstract}

Kata Kunci : Sistem Pakar, Fordward Chaining, Sistem Berbasis Mobile

I.PENDAHULUAN

Pelayanan kesehatan di Indonesia menjadi sesuatu hal yang harus ditingkatkan mengingat jumlah penduduk di Indonesia merupakan salah satu negara terbesar dalam hal kuantitas. Banyak rumah sakit di Indonesia belum mampu menyediakan tenaga ahli kesehatan yang cukup sehingga permasalahan kesehatan menjadi salah satu hal yang utama mengingat banyaknya jenis penyakit yang berkembang yang diakibatkan oleh virus. Penyakit akibat infeksi virus merupakan satu kumpulan jenis-jenis penyakit yang disebabkan oleh virus yang mudah menyerang anakanak[1]. Penelitian ini dilakukan pada Rumkit TK IV 01.07.01 Pematangsiantar yang beralamatkan Jl. Gn. Simanuk-Manuk P. Siantar, Teladan, Siantar Barat, Kota Pematang Siantar, Sumatera Utara. Penyakit akibat infeksi virus pada anak dan gejala-gejala yang ditimbulkan sangat banyak. Suatu gejala penyakit yang disebabkan oleh virus pada makanan dan lingkungan dapat merupakan indikasi dari suatu penyakit yang akan diderita anak[1].

Banyak penyakit yang disebabkan oleh virus yang dapat menyerang anak-anak. Salah satunya adalah penyakit campak. Data menyebutkan, kematian akibat penyakit campakpada anak-anak yang disebabkan oleh virus paramiksovirus. Penyakit campak merupakan salah satu penyakit infeksi yang termasuk dalam prioritas masalah kesehatan, karena penyakit ini dapat dengan mudah menular sehingga dapat menimbulkan wabah atau kejadian luar biasa (KLB). Campak menduduki peringkat ke empat penyebab KLB di Indonesia setelah DBD, diare dan chikungunya[2]. Pada kasus penderita campak untuk dunia, dilaporkan pada tahun 2013 mencapai 777.000 orang, 202.000 di antaranya berasal dari Asssociation of the South east Asia Nation (ASEAN), serta 15 persen kematian akibat campak berasal dari Indonesia. Setiap tahun diperkirakan 30.000 anak Indonesia meninggal karena komplikasi yang di akibatkan campak[3].

Berdasarkan permasalahan diatas, perlu adanya solusi bagi orangtua untuk mengidentifikasi anak yang terkena virus khususnya penyakit campak sebelum mendapatkan tindakan lanjut (medis). Sistem pakar merupakan suatu sistem yang berbasis pengetahuan yang menggunakan pengetahuan manusia yang disimpan dalam database untuk memecahkan permasalahan yang biasanya memerlukan keahlian manusia. Keuntungan dengan menggunakan sistem pakar ini adalah proses penentuan diagnosis dan rekomendasi terapi serta analisisnya dapat dilakukan dengan mudah. Hal ini sangat membantu orangtua untuk melakukan diagnosis gejala awal kepada anak secara konsisten, sehingga dapat mengurangi terjadinya human error dan memberikan penanganan yang 
baik kepada anak sebelum ditanganin oleh ahli (medis). Ada beberapa penelitian terdahulu yang terkait dengan metode forward chaining [4] dan [5].Dari kedua penelitian terdahulu, ada perbedaan mendasar yaitu aplikasi yang digunakan, data penyakit, identifikasi/gejala kasus dan solusi yang diberikan.

Diharapkan penelitian dalam mendiagnosa gejala awal penyakit yang disebabkan oleh virus bagi anak-anak berbasis mobile khususnya campak dengan dasar ilmu kedokteran (obstetri) yang dimiliki seorang pakar dapat membantu orangtua untuk mengetahui penyakit yang mungkin terjadi melalui gejala-gejala yang dirasakan sehingga dapat melakukan tindakan pertolongan pertama.

\section{TINJAUAN PUSTAKA}

\section{A. Sistem Pakar}

Sistem Pakar merupakan bagian KecerdasanBuatanatauArtificialIntelligence dimana pemikiranatauideuntuk membuatsuatu perangkatlunak komputeragar memilikikecerdasan layaknya manusia[6]. Sistem pakar dikatakan sistem mengadopsikan cara kerja atau pengetahuan manusia ke komputer yang dirancang untuk memodelkan kemampuan masalah seperti seorang pakar[7]. Bagian-bagian utama sistem pakar terdapat dua bagian lingkungan dari sistem pakar, sistem pakar juga memiliki beberapa komponen penyusun seperti User Interface, Knowledge, akuisisi pengetahuan, mesininference,workplace, fasilitas penjelasan, perbaikan Knowledge[5]

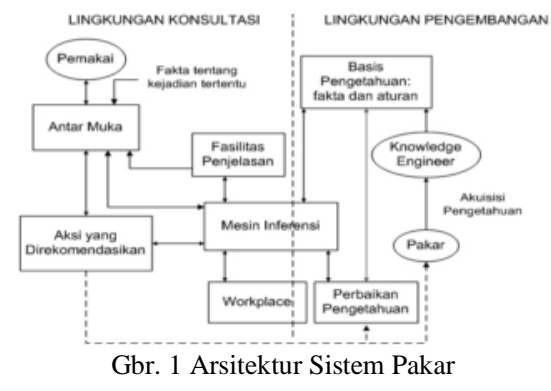

\section{B. Metode Inferensi Forward Chaining}

Forward chaining adalah mekanismepencocokan fakta atau pernyataan yang dimulai dari kondisi (IF) terlebih dahulu dengan aturan(IF-THEN).(IF-THEN). Penalaran dimulai dari fakta terlebih dahulu untuk menguji kebenaran hipotesa.Ilustrasi pelacakan forward chaining dapat dilihat pada Gbr. 2.

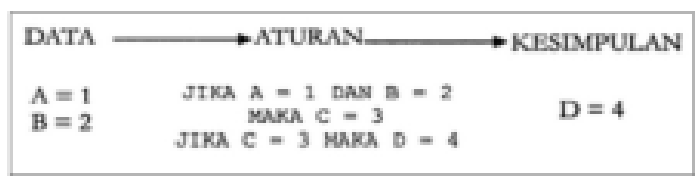

Gbr. 2 Metode Inferensi Forward Chaining

\section{Mobile Web}

Mobile web adalah sebuah website dengantampilan yang diatur atupun disesuaikan dengandengan mobile web browser pada telepon genggam digital atau terminal mobile yang mempunyai fasilitas mobile web browser dan dapat melihat/membaca isi sebuah Beranda situs dalam sebuah format teks khusus[5].

\section{Gejala Awal Penyakit Akibat Virus Pada Anak}

Penyakit akibat virus sangat rentan terjadi pada anak-anak, hal ini disebabkan oleh sistem imunitas yang ada didalam tubuh anak belum terbangun secara sempurna. Dibawah ini akan dijelaskan jenis-jenis penyakit akibat viruspada anak [8].

1.Cacar Air

2.Campak

3.Campak Jerman

4.Gondongan

5.Polio

\section{METODE PENELITIAN}

\section{A. Analisis Dan Perancangan Sistem}

A.1. Algoritma Sistem

Pengguna (user) sistem pakar ini ialah administrator dan orangtua. Administrator yaitu seseorang yang memiliki keahlian (pakar) dalam bidang kedokteran dalam hal ini adalah dokter spesialis anak. Sedangkan pengguna biasa yaitu orangtua sebagai pengakses informasi dan fasilitas sistem pakar ini.

TABEL I

KARAKTERISTIK PENGGUNA

\begin{tabular}{|c|c|c|c|}
\hline Pengguna & Hak Akses & Pendidikan & Pengalaman \\
\hline $\begin{array}{c}\text { Administrator } \\
\text { (Pakar) }\end{array}$ & $\begin{array}{l}\text { Akses } \\
\text { informasi, } \\
\text { login } \\
\text { sebagai } \\
\text { pakar, dan } \\
\text { manipulasi } \\
\text { (tambah, } \\
\text { ubah, dan } \\
\text { hapus) data } \\
\text { di dalam } \\
\text { sistem. }\end{array}$ & $\begin{array}{l}\text { Kedokteran } \\
\text { (dokter } \\
\text { spesialis } \\
\text { anak). }\end{array}$ & $\begin{array}{l}\text { Mampu } \\
\text { mengoperasikan } \\
\text { komputer, pernah } \\
\text { mengakses, dan } \\
\text { memelihara sistem } \\
\text { berbasis android }\end{array}$ \\
\hline
\end{tabular}

\section{A.2. Tabel Keputusan}

Digunakan sebagai aacuan dalam membuat pohon keputusan dan kaidah yang digunakan. Berdasarkan analisa masalah penyakit dan gejala di atas, maka tabel keputusan pada sistem pakar mendiagnosa gejala awal penyakit akibat virus pada anak dapat dilihat pada tabel berikut.

TABEL II

TABEL KEPUTUSAN

\begin{tabular}{|l|l|l|l|l|l|}
\hline \multirow{2}{*}{ Gejala } & \multicolumn{5}{|c|}{ Penyakit } \\
\cline { 2 - 6 } & $\mathrm{P} 001$ & $\mathrm{P} 002$ & $\mathrm{P} 003$ & $\mathrm{P} 004$ & $\mathrm{P} 005$ \\
\hline
\end{tabular}




\begin{tabular}{|l|c|c|c|c|c|}
\hline \multirow{2}{*}{ Gejala } & \multicolumn{5}{|c|}{ Penyakit } \\
\cline { 2 - 6 } & P001 & P002 & P003 & P004 & P005 \\
\hline G001 & X & X & X & X & X \\
\hline G002 & X & & & & \\
\hline G003 & & X & & & \\
\hline G004 & & X & & & \\
\hline G005 & X & & & & \\
\hline G006 & X & & & & \\
\hline G007 & X & & & & \\
\hline G008 & X & & & & \\
\hline G009 & X & & & & \\
\hline G010 & & X & & & \\
\hline G011 & & X & & & \\
\hline G012 & & & X & & \\
\hline G013 & & & X & & \\
\hline G014 & & & & X & \\
\hline G015 & & & & X & \\
\hline G016 & & & & $X$ & \\
\hline G017 & & & & & X \\
\hline G018 & & & & & X \\
\hline G019 & & & & X \\
\hline G020 & & & & \\
\hline G021 & & & & & X \\
\hline
\end{tabular}

Keterangan Penyakit:

P001 $:$ Campak
P002 : Campak Jerman
P003 : Cacar Air
P004 : Gondongan
P005 : Polio

Keterangan Gejala:

G001 : Demam

G002 : Nyeri tenggorokan

G003 : Tenggorokan tampak merah

G004 : Pembengkakan kelenjar getah bening

G005 : Sakit kepala

G006 : Hidung meler

G007 : Batuk

G008 : Nyeri otot

G009 : Mata merah

G010 : Fotofobia (rentan terhadap cahaya, silau)

G011 : Nyeri sendi

G012 : Kemerahan kulit

G013 : Muncul bintik-bintik merah

G014 : Tubuh mengggigil

G015 : Nafsu makan berkurang

G016 : Nyeri ketika mengunyah

G017 : Bengkak pada posisi antara telinga dan rahang

G018 : Muntah

G019 : Diare

G020 : Rewel atau tidak dapat mengendalikan emosi

G021 : Kejang otot, terutama otot betis, leher atau punggung
B. Analisis Pohon Keputusan

Pembentukan pohon keputusan menggunakan binary tree seperti pada gambar berikut:

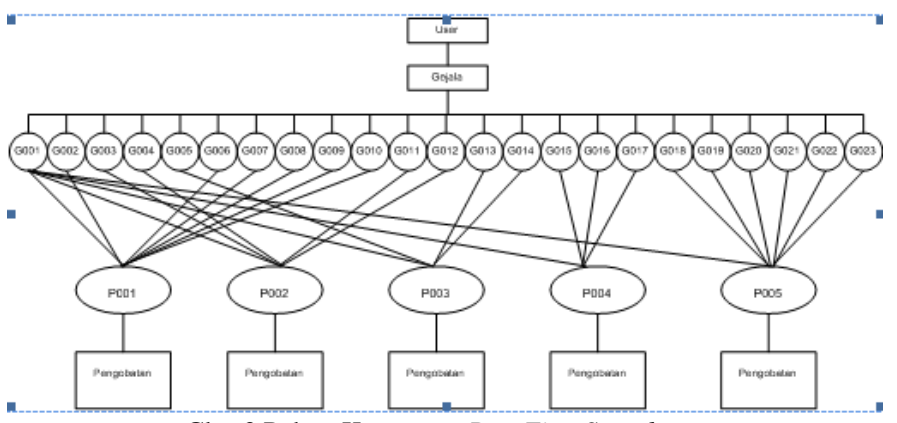

Gbr. 3 Pohon Keputusan Best First Search

C. Kaidah Produksi

Kaidah produksi biasanya dituliskan dalam bentuk jika-maka (IFTHEN). Kaidah ini dapat dikatakan sebagai hubungan impliksi dua bagian, yaitu bagian premise (jika) dan bagian konklusi (maka). Berikut kaidah-kaidah produksi dalam menganalisis penyakit:

Rule 1 : IF G001=Demam

$A N D$ G002=Nyeri Tenggorokan

$A N D$ G007=Hidung Meler

$A N D$ G008=Batuk

$A N D$ G009=Nyeri Otot

$A N D$ G0010=Mata Merah

AND G0011=Fotofobia

THEN P001 =Campak

Rule 2 : IF G001=Demam

AND G003=Tenggorokan Tampak Merah

AND G004=Pembengkakan kelenjar getah bening

$A N D$ G0013=Nyeri Sendi

$A N D$ G0014=Kemerahan kulit

THEN P002=Campak Jerman

Rule 3 : IF G001=Demam

AND G006=Sakit Kepala

$A N D$ G0013=Muncul bintik-bintik merah

AND G0014=Tubuh Mengggigil

THEN P003=CacarAir

Rule 4 : IF G001=Demam

$A N D$ G0015=Nafsu Makan Berkurang

$A N D$ G0016=Nyeri Ketika Mengunyah

AND G0017=Bengkak Pada Posisi Antara Telinga

Dan Rahang

THEN P004=Gondongan

Rule 5 : IF G001=Demam

AND G0018=Muntah

$A N D$ G0019=Diare

$A N D$ G0020=Rewel atau tidak dapat mengendalikan emosi

$A N D$ G0021 = Kejang otot, terutama otot betis, leher atau punggung 


\section{THEN PB005=Polio.}

D. Flowchart Program

Adapun gambaran flowchart dari proses diagnosa penyakit akibat virus pada anak seperti pada Gbr. 4 berikut:

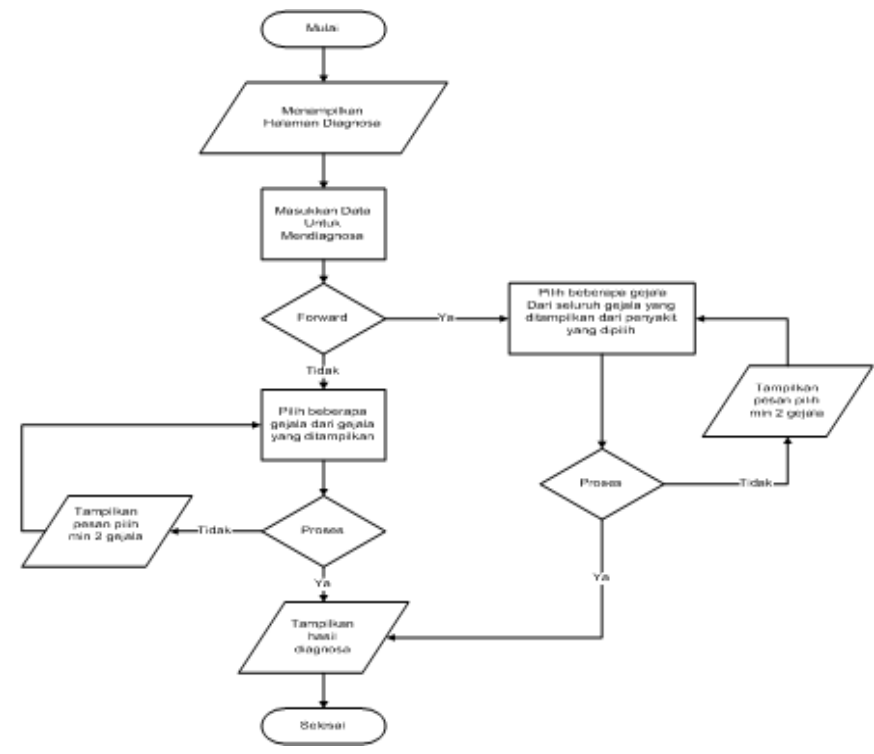

Gbr. 4 Flowchart Proses Diagnosa

\section{HASIL DAN PEMBAHASAN}

Ada beberapa beranda pengguna aplikasi sistem pakar dalam mendiagnosa gejala awal penyebab virus berbasis mobile diantaranya:
a. Beranda Login Pengguna
b. Beranda Utama Sistem
c. Beranda Gejala
d. Beranda Pasien
e. Beranda Penyakit
f. Beranda Diagnosa
g. Beranda Hasil Diagnosa
h. Beranda Data Pengobatan
i. Beranda Data Pencegahan
j. Beranda Data Setting User

Berikut ini tampilan bernda dari setiap aplikasi berbasis mobile dalam mendiagnosa gejala awal penyakit yang disebabkan virus dengan sistem pakar forward chaining.

A. Beranda Login Pengguna

Pada Beranda Login Pengguna terdapat beberapa menu seperti menu gejala, menu virus, menu pasien, menu diagnosa, menu pencegahan dan menu pengobatan seperti pada Gbr. 5 berikut.

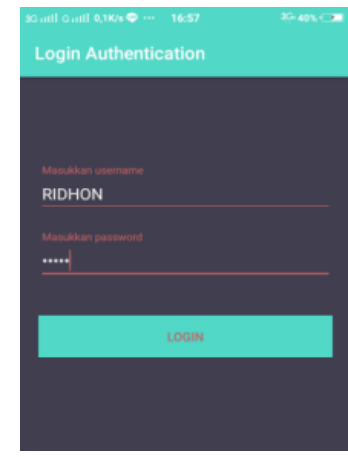

Gbr. 5 Tampilan Beranda Login Pengguna

B. Beranda Utama Sistem

Berandadapat mengakses semua menu yang ada. Adapun tampilan Beranda utama sistem dapat dilihat pada Gbr. 6.

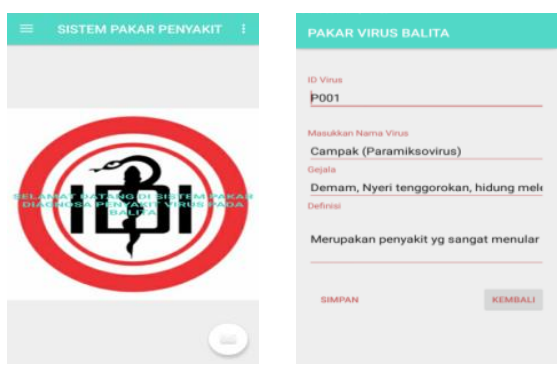

Gbr. 6 Tampilan Beranda Utama Sistem

\section{Beranda Gejala}

Beranda ini berfungsi menampilkan informasi mengenai defenisi gejala. Adapun tampilan Beranda gejala dapat dilihat pada Gbr. 7 .

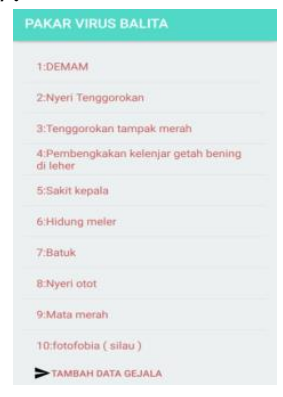

Gbr. 7 Tampilan Beranda Gejala

D. Beranda Pasien

Beranda ini berfungsi menampilkan informasi mengenai data pasien. Adapun tampilan Berandapasien dapat dilihat pada Gbr. 8 . 


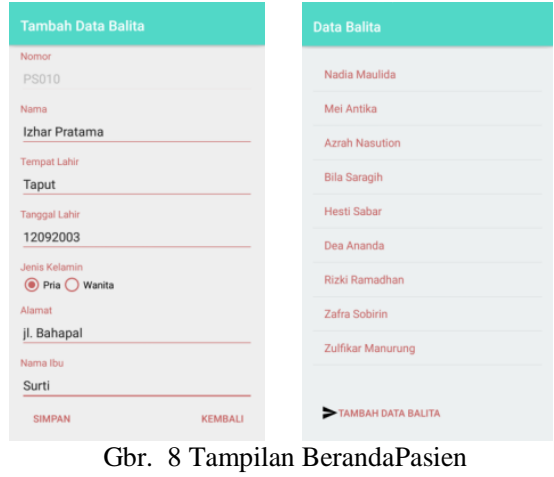

E. Beranda Penyakit

Beranda ini berfungsi mengolah data Penyakit, berikut adalah tampilan dari Beranda Penyakit pada Gbr. 9.

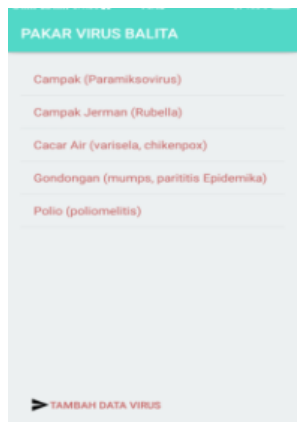

Gbr. 9 Tampilan BerandaData Penyakit

F. Beranda Diagnosa

Melakukan diagnosapasien.Tampilan dari Beranda konsultasi dapat dilihat pada Gbr. 10.
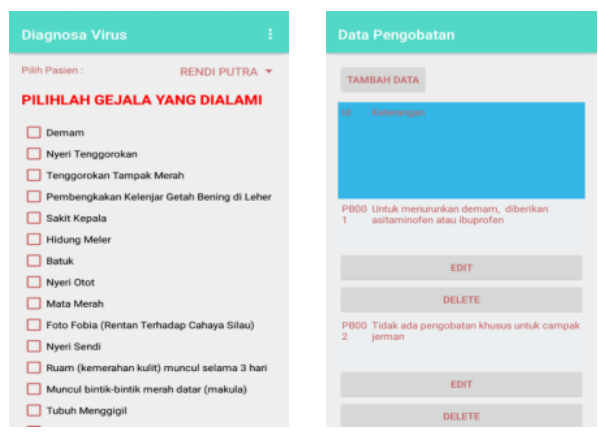

Gbr. 10 Tampilan BerandaDiagnosa

G. Beranda Hasil Diagnosa

Berandaini untuk melihat hasil dari diagnosa yang dilakukan.Tampilan Berandahasil diagnosadapat dilihat pada Gbr. 11.

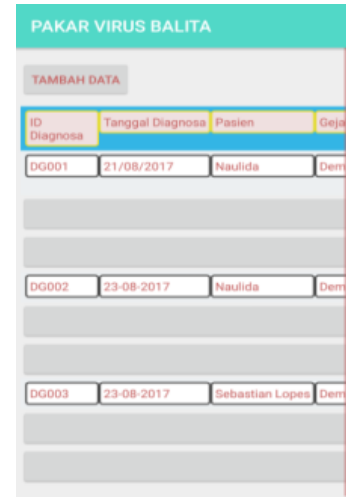

Gbr. 11 Tampilan Beranda Proses Konsultasi

\section{H. Beranda Data Pengobatan}

Berandaini berfungsimelihat hasil dari diagnosa yang telah dilakukan.Tampilan Berandadata pengobatan dapat dilihat pada Gbr. 12.

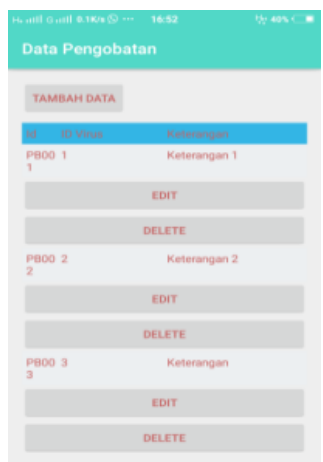

Gbr. 12 Tampilan Beranda Data Pengobatan

I. Beranda Data Pencegahan

Merupakan Beranda untuk melihat hasil dari diagnosa yang telah dilakukan.Tampilan Berandadata Pencegahan dapat dilihat pada Gbr. 13.

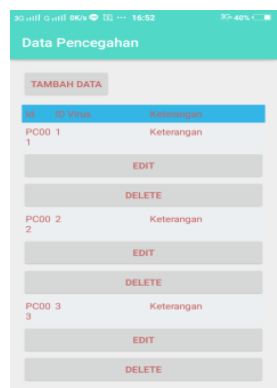

Gbr. 13 Tampilan BerandaData Pencegahan

J. Beranda Data Setting User

Merupakan Beranda untuk melihat hasil dari diagnosa yang telah dilakukan. Tampilan Berandadata Setting User dapat dilihat pada Gbr. 14. 


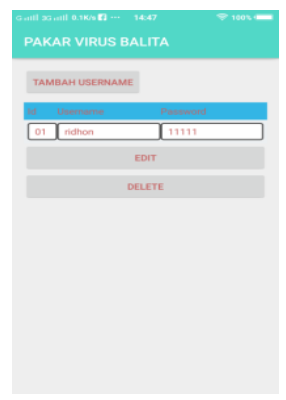

Gbr. 14 Tampilan BerandaData Setting User

\section{A. Kesimpulan}

Ada beberapa kesimpulan yang dapat disampaikan penulis sebagai hasil dari penelitian adalah 1) sistem ini dapat mendiagnosa gejala awal penyakityang disebabkan virus yang menyerang pada anak-anak khususnya penyakit campak berdasarkan gejala-gejala dan 2) aplikasi sistem pakar ini dapat melakukan diagnosa awal terhadap suatu penyakit yang disebabkan virus serta memberikan informasi mengenai definisi, pengobatan serta pencegahannya, sehingga dapat membantu orangtua dalam mengenali gejala serta jenis-jenis penyakit akibat virus pada anak-anak.

\section{UCAPAN TERIMAKASIH}

Terimakasih kepada program studi Sistem Informasi, STIKOM Tunas Bangsa Pematangsiantar atas dukungan dalam terlaksanakannya penelitian ini.

\section{DAFTAR PUSTAKA}

[1] Heri, H. Nasution, and H. S. Pratiw, "Diagnosis Penyakit Akibat Infeksi Virus Certainty Factor" pp. 1-6, 2003.

[2] D. W. Ningtyas and A. Wibowo, "Pengaruh Kualitas Vaksin Campak Terhadap Kejadian Campak Di Kabupaten Pasuruan," J. Berk. Epidemiol., vol. 3, no. 42, pp. 315-326, 2015.

[3] Kementerian Kesehatan RI, "Situasi Imunisasi Di Indonesia," Pusat Data dan Informasi Kementerian Kesehatan RI. pp. 1-11, 2016.

[4] C. H. Mubarok, "Sistem Pakar Diagnosa Penyakit Anak Yang Disebabkan Virus Berbasis Web," pp. 2-6.

[5] M. Silmi, E. A. Sarwoko, and Kushartantya, "Sistem Pakar Berbasis Web Dan Mobile Web Untuk Mendiagnosis Penyakit Darah Pada Manusia Dengan Menggunakan Metode Inferensi Forward Chaining" J. Masy. Inform., vol. 4, no. 7, pp. 31-38, 2011.

[6] A. P. Windarto, L. S. Dewi, and D. Hartama, "Implementation of Artificial Intelligence in Predicting the Value of Indonesian Oil and Gas Exports With BP Algorithm," Int. J. Recent Trends Eng. Res., vol. 3, no. 10, pp. 1-12, 2017.

[7] N. Jarti and R. Trisno "Sistem Pakar Diagnosa Penyakit Alergi Pada Anak Berbasis Web Dengan Metode Forward Chaining" $J$. Edik Inform., vol. 3, no. 2, pp. 197-205, 2017.

[8] Anik, Maryunani. (2010). Ilmu Kesehatan Anak Dalam Kebidanan.(cetakan 1), Jakarta : TIM. 
